\title{
Problems of cooperation of food industry enterprises and their consumer market counterparties in Kirov oblast
}

\author{
E.V. Karanina ${ }^{1, *}$, and E.Y. Selezneva ${ }^{1}$ \\ ${ }^{1}$ Department of Finance and Economic Security, Vyatka State University, Kirov, Russia
}

\begin{abstract}
The paper investigates threats to the relations between local industrial enterprises and consumer market retailers, as well as the place of chain structures in this sector of the economy. To achieve the objectives of the study, food industry and consumer market were analyzed statistically, and the activities of chain structures were researched in-field. It discovers the main trends of the regional consumer market, the impact of retail chains on the changes, and especially the effect of federal and international chains on the structure and development of the consumer market and on the way local manufacturers operate. Based hereon, the main focus areas of coordination and progress in regional-level enterprise-to-retail interaction have been identified as to ensure the economic security of the food industry and the region as a whole.
\end{abstract}

\section{Introduction}

The food industry of the region is aimed at meeting the needs of its residents in everyday food products. Not only the economic security of an enterprise but also the food and economic security of the region as a whole depends on the rational organization of interaction between the enterprises belonging to this industry and their consumer market counterparties. The threats and challenges for food industry enterprises in the consumer market consist in the monopolization of the market by federal and foreign retail chains. The monopolization of the market and the retailers' focus on profit maximization exacerbates the problem of product quality, resulting in the reduction of the social safety of the region's inhabitants, especially in the period of declining real incomes. It is because the consumer market is a sphere of the direct economic impact on people and a social stability factor of the region and the country as a whole.[11] Its balance of commodity flows, the quantity and quality of goods, and prices is a necessary component for the assessment of the life quality of the population [2].

The food supply for the population is one of the most important social and economic issues, as a person's health and well-being depend on the degree of their satisfaction with food. Development of the food market depends on the situation in the agricultural sector as the main source of the resource base formation, on the trade sector, on the customers' solvency, and on the consumer demand.[15]

The food market experiences an adverse effect from the absence of a developed market infrastructure, high levels of costs in production, and the failure of the output to meet the required standards. Positive dynamics of development have been generally observed in the food market of the Kirov region in recent years, its condition has been stable for nearly all the main types of products. The food market of the region has been characterized by saturation, lack of physical shortages, high competition in the food market, an increase in consumer demand, and the growth of retail trade turnover [16].

The concept of "food security" in relation to regions has not been sufficiently established yet, unlike the definition used at the national level and disclosed in the Food Security Doctrine of the Russian Federation.[17] According to the Doctrine,[12] "Food security of the Russian Federation is the state of the country's economy that ensures food independence of the Russian Federation, physical and economic availability of foodstuffs to every citizen that meet the requirements of the laws of the Russian Federation on technical regulation, in quantities not less than the balanced food consumption rates required to support active and healthy lifestyle".[1]

Therefore, resulting from the above issues, the purpose of this article is to analyze the food industry and consumer market development, to identify the problems of interaction between these two sectors, to propose the ways of coordination and further interaction between retail chains and manufacturers at the regional level in order to ensure the economic security of the food sector, as well as the region in general [3].

\footnotetext{
*Corresponding author: karanina@vyatsu.ru
} 


\section{Methods for the analysis of the operation of food industry enterprises and of the consumer market of the kirov region}

The food and food-processing industry of the Kirov region comprises over 400 organizations, including 110 referred to as large and medium ones. The enterprises employ almost 14 thousand people.

This branch of agribusiness is currently one of the most dynamic sectors of the regional economy. The tendency for increasing the output of major foodstuffs continues. In 2015, the turnover of the organizations amounted to 29.4 billion rubles $(115.3 \%$ as compared to 2014), while the index of production was $103.9 \%$.

Table 1. Industrial output of major foodstuffs in the Kirov region, $\%[19]$.

\begin{tabular}{|c|c|c|c|c|c|c|}
\hline & $\mathbf{2 0 1 0}$ & $\mathbf{2 0 1 1}$ & $\mathbf{2 0 1 2}$ & $\mathbf{2 0 1 3}$ & $\mathbf{2 0 1 4}$ & $\mathbf{2 0 1 5}$ \\
\hline $\begin{array}{c}\text { Industrial } \\
\text { output of } \\
\text { foodstuffs, } \\
\text { including } \\
\text { drinks }\end{array}$ & 105,8 & 99,6 & 103,9 & 97,7 & 99,2 & 98,2 \\
\hline $\begin{array}{c}\text { Meat and } \\
\text { edible offal of } \\
\text { slaughtered } \\
\text { animals }\end{array}$ & 134,8 & 102,3 & 106 & 113 & 109,5 & 104,5 \\
\hline $\begin{array}{c}\text { Meat and } \\
\text { edible offal of } \\
\text { poultry }\end{array}$ & 70,3 & 41,5 & 139 & 62,6 & 180,7 & 61,2 \\
\hline Sausages & 98,7 & 99,6 & 104,4 & 92,9 & 94,4 & 93,3 \\
\hline $\begin{array}{c}\text { Canned fruit } \\
\text { and vegetables }\end{array}$ & 96,4 & 99,2 & 97,6 & 97,5 & 103,5 & 96,6 \\
\hline $\begin{array}{c}\text { Canned } \\
\text { vegetables and } \\
\text { mushrooms }\end{array}$ & 112,6 & 65 & 100,6 & 101.3 & 104,6 & 107,6 \\
\hline $\begin{array}{c}\text { Whole milk } \\
\text { products } \\
\text { (calculated for } \\
\text { milk) }\end{array}$ & 97,8 & 97,3 & 104,6 & 104 & 97,4 & 100,7 \\
\hline $\begin{array}{c}\text { Butter and } \\
\text { butter spreads }\end{array}$ & 68,8 & 109,6 & 95,4 & 104 & 114 & 115,5 \\
\hline $\begin{array}{c}\text { Cheeses and } \\
\text { cheese } \\
\text { products }\end{array}$ & 103,2 & 85,2 & 101,2 & 77,2 & 95,3 & 134,9 \\
\hline $\begin{array}{c}\text { Fermented } \\
\text { milk products, } \\
\text { other than sour } \\
\text { cream and } \\
\text { cottage cheese }\end{array}$ & 101,2 & 101,6 & 102,4 & 103,4 & 95,1 & 101,3 \\
\hline $\begin{array}{c}\text { Flour from } \\
\text { cereals, } \\
\text { vegetables and } \\
\text { other crops }\end{array}$ & 110,1 & 105 & 104,2 & 97,3 & 99,4 & 105,4 \\
\hline $\begin{array}{c}\text { Flour from } \\
\text { grains and } \\
\text { legumes }\end{array}$ & 99,3 & 98,5 & 97,7 & 97,3 & 99,4 & 105,4 \\
\hline $\begin{array}{c}\text { Bread and } \\
\text { bakery } \\
\text { products }\end{array}$ & 100,1 & 99,4 & 98,3 & 98,5 & 99,7 & 101,8 \\
\hline Confectionery & 95,4 & 97 & 105,2 & 93,3 & 99,2 & 101,4 \\
\hline Pasta & & & & & & \\
\hline
\end{tabular}

Food industry is an integral part of the region's agribusiness. Many of its branches are developing on the basis of local agricultural products - primarily, meat, milk, butter and cheese. Milling and baking, production of canned fruit and vegetables, distilleries, confectioneries and a number of other industries operate on local and, partially, on imported raw materials.

The distribution of food industry enterprises (Figure 1) over the territory of the region is more even as compared to other industries. They are available in all districts, yet the highest concentration is in the regional center. Kirov is a large food industry hub. The region's biggest dairy works, meat-processing works, confectionery factory, pasta factory, margarine plant, flour mill, fruit and vegetables canning plant and other enterprises are located here. Other significant centers of food industry are Yaransk, Malmyzh, Sovetsk, Slobodskoy, Kotelnich, and Urzhum.

The largest enterprises are: OAO (= plc) "Kirov Meat- Processing Works", OAO "Slobodskoy MeatProcessing Plant", OAO "Kirov Margarine Plant", OAO "Kirov Dairy Works", OAO "Kirov Confectionery and Macaroni Works", OAO "Urzhum distillery", OAO "Slobodskoy Distillery", and OAO " Vyatich ".[18]

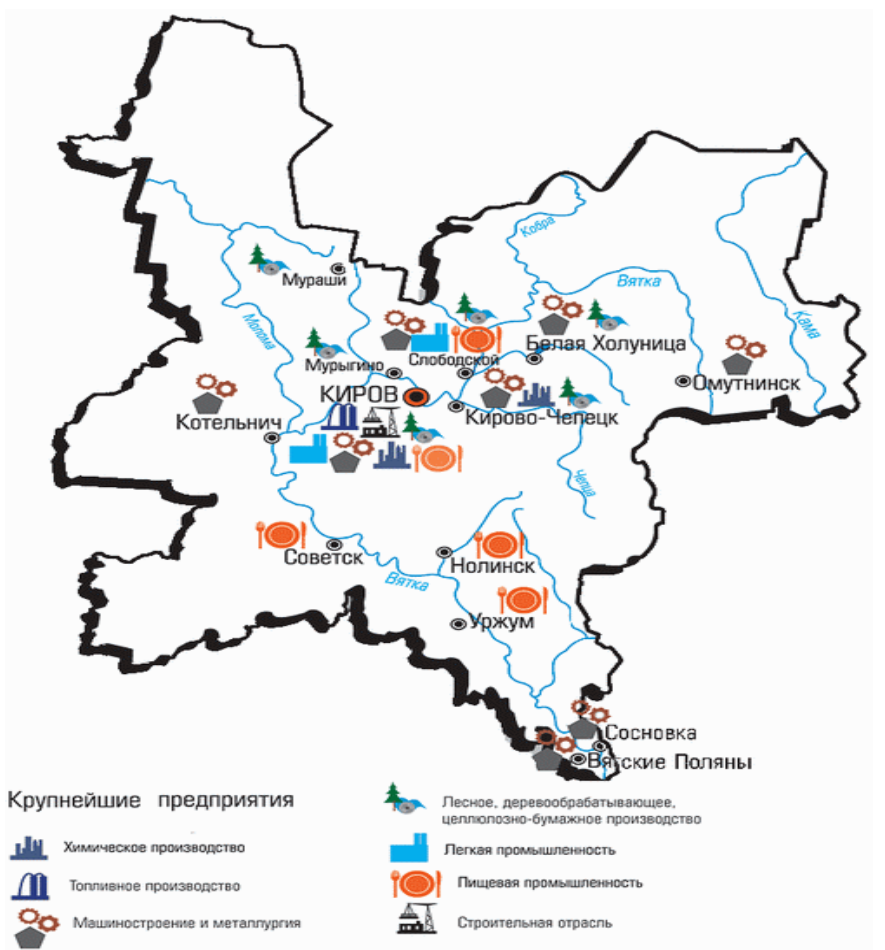

Fig. 1. Territorial distribution of industrial enterprises in the Kirov region.

A significant advantage of the output of food processing enterprises of the Kirov region is its high quality due to the use of natural raw materials. The following table shows the production capacity of food industry organizations of the Kirov region that is required for our analysis.

Table 2. Utilization level of the average annual production capacity of organizations, \%, Kirov region[19].

\begin{tabular}{|c|r|r|r|r|r|r|}
\hline & $\mathbf{2 0 1 0}$ & $\mathbf{2 0 1 1}$ & $\mathbf{2 0 1 2}$ & $\mathbf{2 0 1 3}$ & $\mathbf{2 0 1 4}$ & $\mathbf{2 0 1 5}$ \\
\hline $\begin{array}{c}\text { Meat and edible offal } \\
\text { of slaughtered } \\
\text { animals }\end{array}$ & 37.1 & 42.7 & 50.9 & 58 & 59 & 64.6 \\
\hline $\begin{array}{c}\text { Meat and edible offal } \\
\text { of poultry }\end{array}$ & 56.4 & 20.2 & 31.7 & 18.7 & 25.9 & 55.1 \\
\hline Sausages & 92.5 & 88.5 & 87.4 & 86.8 & 78 & 72.2 \\
\hline
\end{tabular}




\begin{tabular}{|c|c|c|c|c|c|c|}
\hline $\begin{array}{c}\text { Whole milk products } \\
\text { (calculated for milk) }\end{array}$ & 75.2 & 75.9 & 79.6 & 76.7 & 72.4 & 77.3 \\
\hline $\begin{array}{c}\text { Butter and butter } \\
\text { spreads }\end{array}$ & 37.2 & 48.7 & 45.2 & 48.9 & 47.4 & 55.8 \\
\hline $\begin{array}{c}\text { Cheeses and cheese } \\
\text { products }\end{array}$ & 52.8 & 41.5 & 45.5 & 38.1 & 36.9 & 51.2 \\
\hline $\begin{array}{c}\text { Flour from cereals, } \\
\text { vegetables and other } \\
\text { crops }\end{array}$ & 5.9 & 23.9 & 22.8 & 67.8 & 45.8 & 22.7 \\
\hline $\begin{array}{c}\text { Bread and bakery } \\
\text { products }\end{array}$ & 44.3 & 44 & 24 & 23.9 & 25.8 & 26.2 \\
\hline Confectionery & 78.2 & 67.5 & 69.8 & 60.5 & 74.3 & 72.6 \\
\hline Pasta & 80.9 & 75.3 & 34.3 & 52.9 & 52.2 & 36.1 \\
\hline
\end{tabular}

According to these data, the average capacity utilization level of food enterprises is about $50 \%$, the capacity being reduced in most areas.

The food enterprises could work more efficiently if they had free access to the consumer market and rational interaction with trade organizations.

Next, let us have a closer look at the consumer market of the Kirov region and its transformations. 12 thousand enterprises currently operate in the fields of the wholesale trade, retail trade and catering. This amounts to $30.7 \%$ of the total number of business entities in the region. 53.400 people are employed in the consumer market sphere.[7]

The turnover of retail trade amounted to RUR 174.9 billion in 2015 , which is $7.7 \%$ lower than in the same period of the previous year in comparable prices. The share of food products was $48.3 \%$, that of non-food products $-51.7 \%$.

$97.3 \%$ of the retail trade turnover in JanuaryDecember 2015 was formed by trading organizations and individual entrepreneurs selling goods outside retail markets and fairs, the share of sales in retail markets and fairs being $2.7 \%$.

Table 3. Retail trade turnover in the Kirov region, mln rur[19].

\begin{tabular}{|c|c|c|c|c|l|}
\hline $\begin{array}{c}\text { Commoditi } \\
\text { es }\end{array}$ & $\mathbf{2 0 1 1}$ & $\mathbf{2 0 1 2}$ & $\mathbf{2 0 1 3}$ & $\mathbf{2 0 1 4}$ & $\mathbf{2 0 1 5}$ \\
\hline $\begin{array}{c}\text { Foodstuffs, } \\
\text { including } \\
\text { drinks and } \\
\text { tobacco } \\
\text { products }\end{array}$ & 58130.5 & 64688.9 & 71819.8 & 77855.8 & 84224. \\
\hline $\begin{array}{c}\text { Non-food } \\
\text { products } \\
\text { (without } \\
\text { tobacco) }\end{array}$ & 58486.9 & 66589.3 & 77409.6 & 87208.9 & 90651. \\
\hline
\end{tabular}

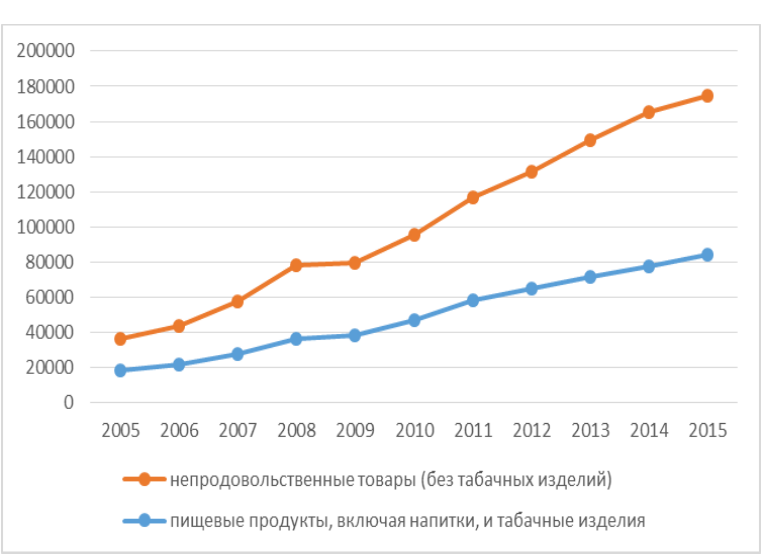

Fig. 2. Retail trade turnover in the Kirov region.
Table 4. Share of retail chains in the retail trade turnover of the subjects of the Russian Federation [19].

\begin{tabular}{|c|c|c|c|c|c|c|}
\hline \multirow[t]{2}{*}{ Territory } & \multicolumn{5}{|c|}{$\begin{array}{c}\text { Share of the retail trade turnover of } \\
\text { retail chains in the total retail trade } \\
\text { turnover }\end{array}$} & \multirow[t]{2}{*}{$\begin{array}{c}\% \text { of } \\
\text { change }\end{array}$} \\
\hline & 2011 & 2012 & 2013 & 2014 & 2015 & \\
\hline $\begin{array}{c}\text { Russian } \\
\text { Federation }\end{array}$ & 18.4 & 20.5 & 21.9 & 22.9 & 25.0 & 6.6 \\
\hline $\begin{array}{l}\text { Volga } \\
\text { Federal } \\
\text { District }\end{array}$ & 16.8 & 18.8 & 20.5 & 22.3 & 23.4 & 6.6 \\
\hline Kirov region & 19.3 & 21.0 & 23.6 & 25.6 & 28.2 & 8.9 \\
\hline
\end{tabular}

The table gives grounds for the conclusion that there is a trend for an increase of the retail chains turnover, the figure for the Kirov region being above the average for both Russia and the Volga Federal District.

According to the data of the Russian Federal State Statistics Service (Rosstat), the share of retail chains has been steadily increasing, and this trend will continue. The expansion of retail chains is rather heterogeneous, both over federal districts and within the regions of the Volga Federal District. This is due to both the market opportunities and the local authorities' choice of policies in relation to retail chains [6].

National and international retail chains continue to actively involve the leading regional manufacturers in their expanding logistics schemes, as well as to develop production lines within their own companies. This is evidenced, in particular, by the emergence of agricultural holdings within one commercial brand. E.g., one of the largest suppliers of goods under the "Magnit" chain brands is OOO (= pvt. ltd. co.) "TD-Holding." Yet it should be noted that unfair competition is also present in the market: a new manufacturer may be involved in the chain and then deliberately made bankrupt or cut off from the sources of raw materials. All this enables a monopoly on a particular regional market [13].

Based on the Rosstat data, we should study the percentage of the presence of retailers with the participation of foreign capital in some regional markets.

Table 4. Share of retail chains with the participation of foreign capital in regional markets, $\%[19]$.

\begin{tabular}{|l|c|c|c|c|c|c|c|}
\hline Territory & $\mathbf{2 0 1 0}$ & $\mathbf{2 0 1 1}$ & $\mathbf{2 0 1 2}$ & $\mathbf{2 0 1 3}$ & $\mathbf{2 0 1 4}$ & $\mathbf{2 0 1 5}$ & $\begin{array}{l}\text { Rate, } \\
+-\end{array}$ \\
\hline $\begin{array}{l}\text { Russian } \\
\text { Federation, } \\
\text { bn RUR }\end{array}$ & 39.6 & 52.2 & 46.9 & 52.4 & 59.2 & 74.5 & 51.3 \\
\hline $\begin{array}{l}\text { Volga } \\
\text { Federal } \\
\text { District }\end{array}$ & 42.8 & 55.4 & 50.1 & 55.6 & 62.4 & 77.7 & 50.3 \\
\hline Kirov region & 40.8 & 53.4 & 48.1 & 53.6 & 60.4 & 75.7 & 50.6 \\
\hline
\end{tabular}

On the basis of the data presented, it can be concluded that the presence of non-resident retail chains has increased more than 3 times, which can become a threat to the economic and food security, especially during the implementation of the imports substitution concept.

The major retail chains operating in the market of the Kirov region have been analyzed in our research. The information was taken from official web sites of the chains and from professional portals. 
The following retail chains operate in the 39 municipal districts and 6 boroughs of the Kirov region: the hypermarket "Vremya prostora", "Carousel", "Metro Cash \& Carry", ZAO "Tander" ("Magnit" stores), OOO "Tamerlan" ("Pyatyorochka" stores); OOO "Sever", "Sever-2", etc. ("Globus" and "Vsyo na svete" stores); OOO "Kirovsnabservis" ("Produktovaya lavka" stores); OOO “Aitek" ("Oasis" stores), etc.[14]

The results are shown in Table VI.

Table 5. Major retail chains operating in the market of the Kirov region [20].

\begin{tabular}{|c|c|c|c|c|}
\hline $\begin{array}{l}\text { Stores, their } \\
\text { format }\end{array}$ & $\begin{array}{l}\text { Number } \\
\text { of stores }\end{array}$ & $\begin{array}{c}\text { Year } \\
\text { arrive } \\
\text { d in } \\
\text { Kirov } \\
\end{array}$ & $\begin{array}{l}\text { Type of } \\
\text { chain }\end{array}$ & $\begin{array}{l}\text { Owners' } \\
\text { residence }\end{array}$ \\
\hline $\begin{array}{c}\text { "Magnit" } \\
\text { self-service, } \\
\text { next-door store }\end{array}$ & 107 & 2010 & Federal & $\begin{array}{c}\text { Russia, } \\
\text { Krasnodar, } \\
\text { with } \\
\text { foreign } \\
\text { capital }\end{array}$ \\
\hline $\begin{array}{c}\text { "Bristol" } \\
\text { next-door store, } \\
\text { alcomarket }\end{array}$ & 78 & 2013 & Federal & $\begin{array}{c}\text { Russia, } \\
\text { Nizhny } \\
\text { Novgorod, } \\
\text { with } \\
\text { foreign } \\
\text { capital } \\
\end{array}$ \\
\hline $\begin{array}{l}\text { X5 Retail Group } \\
\text { ("Carousel", } \\
\text { "Pyatyorochka") } \\
\text { supermarket, } \\
\text { self-service, } \\
\text { next-door store }\end{array}$ & 75 & 2011. & $\begin{array}{c}\text { Internatio } \\
\text { nal }\end{array}$ & Netherlands \\
\hline $\begin{array}{c}\text { "Globus" } \\
\text { supermarket }\end{array}$ & 38 & 2000 & Regional & $\begin{array}{l}\text { Russia, } \\
\text { Kirov }\end{array}$ \\
\hline $\begin{array}{l}\text { "Krasnoye I } \\
\text { beloye" } \\
\text { next-door store, } \\
\text { alcomarket }\end{array}$ & 31 & 2013 & Federal & $\begin{array}{c}\text { Russia, } \\
\text { Chelyabins } \\
\text { k, } \\
\text { with } \\
\text { foreign } \\
\text { capital } \\
\end{array}$ \\
\hline $\begin{array}{c}\text { "Oasis" } \\
\text { next-door store, } \\
\text { alcomarket }\end{array}$ & 28 & 1998 & Regional & $\begin{array}{l}\text { Russia, } \\
\text { Kirov }\end{array}$ \\
\hline $\begin{array}{l}\text { "Produktovaya } \\
\text { lavka" } \\
\text { self-service }\end{array}$ & 22 & 1992 & Regional & $\begin{array}{l}\text { Russia, } \\
\text { Kirov }\end{array}$ \\
\hline $\begin{array}{c}\text { Krasnogorsky" } \\
\text { self-service }\end{array}$ & 15 & 2001 & Regional & $\begin{array}{l}\text { Russia, } \\
\text { Kirov }\end{array}$ \\
\hline $\begin{array}{l}\text { "Nikolsky" } \\
\text { (Poley) } \\
\quad \text { self-service }\end{array}$ & 15 & 1996 & Regional & $\begin{array}{l}\text { Russia, } \\
\text { Kirov }\end{array}$ \\
\hline $\begin{array}{c}\text { "Samobranka" } \\
\text { supermarket }\end{array}$ & 8 & 2004 & Regional & $\begin{array}{l}\text { Russia, } \\
\text { Kirov }\end{array}$ \\
\hline $\begin{array}{c}\text { "Svetofor" } \\
\text { Warehouse-store }\end{array}$ & 4 & 2015 & Regional & $\begin{array}{c}\text { Russia, } \\
\text { Kirov, with } \\
\text { foreign } \\
\text { capital }\end{array}$ \\
\hline $\begin{array}{c}\text { "Zelyony ugol" } \\
\text { eco-store }\end{array}$ & 4 & 2015 & Regional & $\begin{array}{l}\text { Russia, } \\
\text { Kirov }\end{array}$ \\
\hline $\begin{array}{c}\text { METRO Cash \& } \\
\text { Carry } \\
\text { International } \\
\text { GmbH } \\
\text { hypermarket }\end{array}$ & 1 & 2009 & $\begin{array}{c}\text { Internatio } \\
\text { nal }\end{array}$ & Germany \\
\hline $\begin{array}{c}\text { "Vremya } \\
\text { prostora" } \\
\text { hypermarket }\end{array}$ & 1 & 2006 & Regional & $\begin{array}{l}\text { Russia, } \\
\text { Kirov }\end{array}$ \\
\hline
\end{tabular}

In relation to the total number of trade enterprises (including small businesses) operating in the regional consumer market, their share may be small, but in terms of other indicators, primarily turnover, their share is more than $50 \%$, and it tends to grow rapidly.

\section{Results of the analysis of the impact of consumer market organizations on the operation of regional manufacturers}

Expansion of the world chain companies on regional markets has both positive and negative consequences. Government regulation at both the national and regional level should play a significant role in smoothing the negative consequences of the expansion of chain companies in regional markets. It should be primarily aimed at protecting and supporting small trade enterprises and the implementation of anti-monopoly measures - in particular, combatting unfair competition and monopoly, controlling the product quality and prices, regulating relations with suppliers. All these matters were to be solved by the federal law "On the bases of the government regulation of commercial activities in the Russian Federation", yet unfortunately, it did not solve any in essence.[8]

On June 24, 2016, the State Duma adopted, at its last plenary meeting, in the second and third final reading, amendments to the law on trade, according to which the maximum amount of remuneration received by retail chains from the supplier for the purchase of a certain quantity of goods (retro bonuses) is reduced from $10 \%$ to $5 \%$. In addition, it is proposed to significantly decrease the time period within which chains currently pay for the delivery of goods. The law increases the role of the Federal Antimonopoly Service so that this agency monitored the observance of the norms of the new edition of the law on trade, as well as regulated relations between suppliers, manufacturers and retailers. The next year will show to what extent the amendments can solve the problems of the retail market.[10]

The share of federal (international) chains is increasing from year to year, resulting in a decrease in the share of regional and local chains. The problem of the relationship between these chains and local manufacturers should be noted. In fact, the chains force their suppliers to agree to all the proposed terms, and the suppliers do it so that not to lose the market, to be able to sell their products, often perishable ones.

For example, the Director for corporate relations of the "X5 Retail Group N.V.", M.V. Suslov openly stated that in order to survive, suppliers should agree to the conditions of his chain. We quote: "... the proportion of retailers abroad is around $80-90 \%$, while in Russia large retail chains account for only one third of the commercial market. However, the market is moving steadily towards consolidation, and the Russian manufacturers should be prepared for the fact that in the domestic segment, the share of retail chains will continue to grow. Therefore the manufacturers who manage today to build relations with chains, manage to understand how to work with them will secure further development for themselves ...". M.V. Suslov identified the following policy options for the owners of small shops or small chains, as well as for small manufacturers for the time being: either changing to a narrow specialization, in which chains are not able to 
compete in the assortment of a certain product group, or selling the business to a chain company. In addition, manufacturers can try to take their products to the federal level, that is, to become a federal brand, or begin to make products under a large chain's own brand.[18]

The Kirov manufacturers, in their turn, draw the attention of the retailer's top managers to insufficient flexibility in considering their requests for cooperation. Representatives of the Russian Federal Service for Surveillance on Consumer Rights Protection and Human Wellbeing in the Kirov region noted that federal chains have more problems with the quality of products sold.

There are also many complaints about the federal retail chain "Magnit". Goods manufacturers are dissatisfied with the cooperation with this federal chain, which, in their opinion, washes away Kirov goods from the market. And the figure of $28 \%$ that the directors of the branch give as an indicator of the amount of goods from Kirov manufacturers on the shelves of "Magnit" is untrue. Public bodies are also concerned about the fact that apart from other problems, the monthly turnover of "Magnit" is more than RUR 900 million, while the company is not registered in the Kirov region - and the money goes outside the region. This company supplants Kirov manufacturers.

Some entrepreneurs expressed complaints about the quality of the products that citizens acquire in the "Magnit" chain. Among other things, top managers of the "Magnit" chain plan to open a distribution center in the Kirov region in 2017 which should make life easier for our suppliers. The management of the "Magnit" chain promises almost the moon for the region with the opening of this center: major investments (more than RUR 1 billion), about 1 thousand jobs, an annual replenishment of the regional budget in the amount of about RUR 100 million, opportunities for suppliers, numerous social guarantees for employees (pensionable service, discounted tickets to sanatoria, etc.).

Kirov manufacturers view this prospect with suspicion: some of them have already dealt with distribution centers in other regions, where it happens that goods are returned almost without explanation, and it is very difficult to achieve justice at the top of the "Magnit" management.

There is also a problem that federal chains have assumed the right to determine what manufacturers to work with and with what ones not to work, what bonuses and discounts to apply, often exhibiting immoderate appetites. For example, they ask for a 30\% discount, while the food industry of the Kirov region for its most part has only $5-10 \%$ profitability. Amendments to the federal law "On Trade" might solve this set of problems.

The federal retail chains, in their turn, speak about the non-competitive prices given by the local suppliers. But a low price does not guarantee the quality of the goods. To increase the shelf life, preservatives are used, as well as substitutes, flavor and colour enhancers. Although permitted for the use in production they definitely deteriorate characteristics of the goods.

\section{Conclusion}

In general, the solution of the acute problems concerning interaction between the manufacturers of the Kirov region and large retail chains includes the following components:

- prevention of excessive concentration in the retail trade in foodstuffs;

- maintaining a balance of large, medium and small forms of retail trade;

- ensuring the preservation of the diversity of goods distribution and of the retail trade organization formats;

- support for small businesses in the retail sector;

- reduction of administrative barriers and administrative regulation in the retail sector, which would contribute to the development of a competitive environment and the improvement of business efficiency; - coordination of the interaction between manufacturers and chains by modelling the norms of the presence of food industry enterprises in the turnover of retail chains, a program-oriented and regulatory approach that would take into account the interests of local manufacturers;

- use of the instruments for a moderate regional protectionism.[4]

One can identify the following instruments that are necessary to preserve the region's food security:

- additional voluntary certification and labeling;

- establishing specific bans (temporal, territorial, assortment, sales channels of distribution networks);

- directions to distributors requiring to increase sales of locally produced goods;

- price control in conjunction with the Federal Antimonopoly Service;

- establishment of quotas for imported products.

In order to support the agro-industrial complex, the following measures can be used:

- pressure on municipalities for monitoring the sales of locally produced goods through retail chains;

- preferences to local manufacturers.[9]

The conceptual approach to the development of the food industry should be based on the preservation of the food security of the country and the region, and on the scientific approach of modelling the placement of a trade outlet in the territory.[5] The concept should include instruments for regional protectionism aimed at increasing the efficiency of local industrial enterprises.

\section{References}

1. G.S. Bondareva, Bulletin of Kemerovo State University, 3, 4, 24-29 (2013)

2. N.A. Vasilyeva, Russian Entrepreneurship, 4, 103107 (2012)

3. O.A. Inevatova, E.P. Prokofieva, Bulletin of Orenburg State University, 13, 210-214 (2011)

4. E.V. Karanina, Financial and economic security: the regional aspect (Scientific Publishing Center: Discovery North Charleston, SC, USA, 2015) 
5. E.V. Karanina, D.A. Loginov, Theoretical and methodological aspects of the analysis of the risk system of a regional economy (Scientific Publishing Center: Discovery, North Charleston, SC, USA, 2015)

6. E.V. Karanina, The economic security of the state, region and enterprise: formation and provision taking into account the risk factors (Staraya Vyatka, Kirov, 2015)

7. E.V. Karanina, A.V. Evstratova, Economy and Management: Problems and Solutions, 12, 146-153 (2015)

8. V.V. Kurchenkov, O.V. Fetisov, T.V. Chigareva, Bulletin of Astrakhan State Technical University, Series: Economy, 1, 36-41 (2013)

9. N.V. Muratov, Proceedings of the International scientific and practical conference with elements of scientific schools, 2, 16-23 (2013)

10. N.V. Muratov, Business in Law, 6, 34-39 (2015)

11. N.V. Muratov, Scientific Review. Series: Economics and Law, 6, 56-63 (2015)

12. On the action plan for the implementation of the provisions of the food safety doctrine of the Russian Federaton: the decree of the Government of the Russian Federation, of 2010 376-p (2010)
13. E.Y. Selezneva, Bulletin of Russian State University for the Humanities. Series: Economics. Management. Law, 12, 218-222 (2012)

14. E.Y. Selezneva, Concept, 11, 27-30 (2013)

15. A.E. Chusova, The consumer market of Russia: the diagnostics of the industry and regional issues (Institute of Economics, the Ural Branch of the Russian Academy of Sciences, Yekaterinburg, 2012)

16. A.E. Chusova, Scientific and technical bulletin of St. Petersburg Polytechnic University. Series: Economics, 2, 103-108 (2012)

17. A.E. Chusova, Proceedings of the I All-Russian symposium on regional economics, Institutions of regional innovation development. Institutions of the self-development of territories of different levels. Current regional policy of the government, 164-166 (2011)

18. Vyatka Chamber of Commerce and Industry: official web site. http: //www.vcci.ruyu

19. The territorial body of the Federal State Statistics Service for the Kirov region: official web site. http://www.kirovreg.ru/econom/industry/import.php

20. Federal Tax Service: official web site. http://www.nalog.ru/nal_statistik/analit/ 